\title{
LUDWIG VON MISES'S PRAXEOLOGY AS THE FOUNDATION OF CHRISTIAN ECONOMIC PERSONALISM
}

\begin{abstract}
What can an economist and agnostic tell a theologian about man? In contrast to mainstream economics, which today dominate all universities in the world, Ludwig von Mises $(+1973)$ is interested in real man in action, not a fictitious homo oeconomicus. At one time Gregory M. A. Gronbacher (1998), an American philosopher, proposed a synthesis of Christian personalism with the free market economy developed by the Austrian School of Economics. His idea prompted me to use Mises's praxeology to understand and describe human action in the socio-economic sphere from the perspective of Catholic Social Teaching. At that time I understood how important were economic laws for the proper moral evaluation of human action.

Mises in his treaty on economics Human Action developed his own anthropological concept of man. The Austrian economist never used the expression "person" to describe and analyze human action, but analyzing his economic system I was able to discover that he did not understand the free market economy as an abstract being composed of mechanical elements. According to him, the prerequisite for human activity is the desire to replace a less satisfactory state of affairs with a more satisfying one. Mises's man is guided by his own scale of values and builds it up on the basis of a goal he freely chooses. Mises also takes into account that the market is only a part of reality and human activity.
\end{abstract}

Keywords: praxeology, Mises, christian, personalism

The Austrian economist does not speculate about economics, but he studies and discovers how a real person works in a world limited by the scarcity of external factors. Theology and Mises speak of man in action. Theology speaks of a person and his/her deeds, and Mises talks about an individual and his activities in the economic sphere. They both use different words, but as a theologian I see that they contain the same concepts which define human action as free, intelligent, and transcendent. At the end of my work on Mises entitled Two people from Galicia ${ }^{1}$ I could have written that the anthropological basis of man in the Austrian economist's writings is consistent with the Church's vision of man. 
A theologian needs an extensive conceptual basis, without which a deeper theological and moral analysis of human action in the free market would be difficult and incomplete. Without referring to the laws governing human action in the economic sphere, Christian economic personalism would be detached from real men and Mises's praxeology seems to be a perfect tool for theologians. I will present it by analyzing a couple of the key concepts relevant to Catholic Social Teaching.

\section{The Subjectivity of Human Choices}

John Paul II (+2005) in his encyclical Centesimus annus recognizes the rightness of profit as the first indicator of enterprise development, because it is a sign that the production factors have been properly applied and human needs are met ${ }^{2}$. For the first time in Catholic Social Teaching, the Polish pope who experienced socialist rule himself wrote positively about profit. For many critics of the free market, "profit" is still a pejorative term, a synonym of exploitation and abuse. Mises comes to help, clearly showing that every human activity is aimed at making a profit, and that is why it is difficult to imagine a situation in which people could function on different principles. Man always thinks in terms of profit and loss. The personalistic analysis of human behavior using Mises's praxeology allows us to discover that this category of thought is universal and is not limited to the field of economics.

For the Austrian School of Economics, physical and mental state as well as well-being are subjective concepts. The value of market goods is a relationship that is deeply rooted in personal, subjective acts of valuation and depends on individual evaluation and specific choice. Subjectivity in Mises's writings means a person who is a conscious subject in action. Subjectivity understood in this way should be distinguished from ethical subjectivism which claims that moral truth is subjective and constitutes a product of personal awareness ${ }^{3}$. The Austrian economist claims that man in action is guided by his own scale of values. The goals of human action are subjective and that is why every human being has to designate them. However, this has nothing to do with moral relativism and autonomous morality, because every man must discover God himself as the goal of his life. Personalism based on subjectivity does not weaken human action in accordance with the objective truth ${ }^{4}$. Man's creativity and freedom are not expressed in the invention of the natural law, but in the experience of the law "written in his heart" by God, which means in his conscience. 
The Austrian philosopher recognizes an essential element of the free market, which is very often not noticed by the Catholic Social Teaching. The free market economy is characterized by the fact that every acting person is a means and at the same time an end for himself and a means for other people in their attempts to achieve their own goals and benefits. The concept of consumer sovereignty does not therefore mean tyranny and oppression. Man is fully free to counter the tastes of consumers.

Economic activities on the free market are never a zero-sum game, where every profit must mean someone's loss, and in economic transactions there are always losers. Mises clearly showed that a transaction in a system of undistorted market economy is always beneficial for both the buyer and the seller, because otherwise it would never happen. The condition of exchange is always a space of freedom. According to Mises the combination of freedom with subjectivity guarantees that man's action corresponds with his dignity, which belongs only to him as person.

\section{Private Property as an Element of Economic Calculation}

In the contemporary Social Teaching of the Church, there is often an idea that the public authority has the right to make sure that someone does not abuse private property to the detriment of the public good ${ }^{5}$. It is not until Pope John Paul II that it appeared quite clearly that the substitute state interventions should be limited as far as possible in time. Mises provides additional arguments that in the free market economy there is no need to force cooperation by means of orders and prohibitions, because there is no conflict between the adaptation of the individual to the needs of the productive effort of society and its own goals. The Austrian economist convincingly demonstrated that socialist central planning and the overthrow of private property always leads to the elimination of economic calculation, and that means the end of all economic rationality. Monetary calculation is a necessary compass that enables people to move around in the social division of the labor system. Depriving a person of the possibility of private possession is therefore a serious obstacle in free decision making.

Mises aptly notes that in the pre-capitalist social systems, where the economic self-sufficiency of individual family farms predominated, having production or consumption goods meant having them only for themselves. In the free market system, the mere fact of having means of production com- 
pels him to comply with the wishes of customers, because the ultimate goal of each production is consumption. In order to precisely determine which types of goods are to be produced using rare resources in the possession of the public, the preferences of the consumer should be properly discovered. In order to describe this state of affairs, the Austrian economist accepts the concept of "consumers' sovereignty 6. ." Mises argues that contrary to the common view according to which the "bourgeois class" exercises over all governments, there is the opposite. An entrepreneur cannot run his business in any way he wants, if he does not want to go bankrupt. He is the owner of the means of production, but in reality he is only a temporary steward, because he must produce according to the demand and wishes of consumers.

The Second Vatican Council Fathers suggest that ownership often becomes an occasion for greed, which becomes a pretext for questioning law itself. Mises considers this way of thinking wrong, because their authors do not see the significance of the forces that they condemn as the immoral functioning of the market. The market is not dealing with ideal individuals. He must take into account man as he is. Replacing the motive of profit - which is the leading factor of private ownership of the means of production - by "moral" motives, would cause the destruction of the purposefulness and efficiency of the market. Selfishness, greed, and the individual's striving to achieve his own goals are not contrary to the totality of the social production process, as long as the man in action for his own interests remains in the space delimited by the limits of private property.

\section{The Principle of Universal Use and the Universal Destination of Goods}

Thanks to Mises, we can see more clearly that private property allows man not only to better manage material goods, but in the free market is associated with the universal destiny of goods. We can achieve this within the limits set by private property, and the task of the state should be limited only to its protection as a necessary means to achieve this goal. Mises shows that in the free market economy, the possession of means of production is always connected with social duty, and state intervention is not necessary. Private property is guided by its internal power of disposal and the efficient use of material goods, which cannot be replaced by anything else. 
In Catholic Social Teaching there has been a slow evolution of the view of the relationship between private property and the principle of the universal destination of goods. In the last of his social encyclicals Centesiums annus, John Paul II stated that private property is a guarantee of creation of work and human development for all. The Pope drew attention to this earlier in the encyclical Laborem exercens, in which he showed that the takeover of means of production by the state cannot be tantamount to "socialization", for one can speak about socializing only when the subject character of society is ensured. This goal can be achieved only on the basis of the work each person can consider himself a part-owner of the great workshop 7 . As Mises showed, this takes place only in a free market economy, in which the subjectivity of society is guaranteed by the consumers' sovereignty. What is to be produced is not determined by entrepreneurs, farmers, or capitalists, but by consumers. They decide not only about the prices of consumer goods, but also about the prices of all production factors.

The Ownership of means of production is not a privilege but a social obligation. Capitalists are forced to take care of consumers' needs and thus realize the universal destination of goods. John Paul II points out that the ability to recognize in time the needs of others and the systems of production factors most suitable to satisfy them is an important source of wealth for modern man ${ }^{8}$. According to the pope, the ownership of the means of production is only valid if it serves a useful job ${ }^{9}$. According to Mises, this feature of private ownership can only be realized in the free market economy. The one who does not use his property for the best service of consumers is punished with losses, and if from these losses he does not learn and does not change his behavior, he loses all his property.

\section{The relationship between work and capital}

Another concept that thanks to Mises is deepened in the Catholic Social Teaching is the relationship between work and capital. This relationship is often marked by an old conflict. Historical experience shows that it was rather in the past a consequence of socializing the means of production in the communist countries and depriving people of capital, that is, production factors. This made it impossible for them to carry out economic calculations and as a result the production process was depersonalized. On the other hand the lack of a formal system of property which could grasp the economic potential of resources and confer it on a form easy to carry and control, did 
not allow to create capital understood as an abstract idea ${ }^{10}$. Such a situation had to lead to a conflict, because the principle of their complementarity was shaken.

The Church teaches that work, by its personal nature, exceeds every other factor of production, and assumes its priority over capital ${ }^{11}$. John Paul II by capital understands a group of means of production being an instrument and superior cause of the process of production, and he treats work as the efficient cause of this process. Work according to the Austrian economist is the use of forces and abilities by people as a means to remove anxiety, and capital is the basic intellectual tool of activities undertaken in the market economy, which does not exist outside the mind of the acting individual.

In his encyclical Centesimus annus John Paul II states that the basic capital and "decisive factor" 12 that man has is himself, and its value is expressed in knowledge, creativity, and entrepreneurship. This all draws a new perspective for understanding the relationship between work and capital, where the subjective dimension of the work of a laborer is clearly emphasized ${ }^{13}$. Church documents do not say expressis verbis about capital as an element of economic calculation, but such a concept of capital is already included in the subjective dimension of work, which is the basis of all activities in the market economy.

\section{The subjective dimension of work}

Catholic Social Teaching also points to the new danger of separating labor from capital in the era of globalization and scientific and technical progress. The Austrian economist helps to understand that this danger is the result of state intervention which is a main threat to the subjective and personal character of human work.

For Mises, work is the use of physiological functions and manifestations of human life as a means of production to eliminate discomfort and achieve the intended purpose. Thinking about working in the category of means and tools does not yet entitle us to say that the concept of work in the Austrian economist's writings automatically takes on the subject matter. First of all, according to him work has a subjective dimension, because in a free market economy a person can independently undertake various activities that belong to the work process and at the same time correspond to his personal calling. Mises takes into account this dual dimension of human work, because he knows well that man is not only a provider of the 
factor of production, which is work, but also he is a human being from whom his or her activity cannot be separated.

In a free market economy, there is no economic dictatorship that would bring an employee to the level of a pure production tool. Mises admits that an employee sells his services just like others sell goods, but the employer is not the master of the employee, only someone who buys these services and has to pay a certain price for them. However, in any case, we cannot say that the axiological qualification of such an exchange has been reduced only to the criteria of effectiveness and economics. We are dealing here with a real personalistic criterion. Labor is understood and treated as the act of the person (actus personae) and at the same time an act toward a person (actus erga personam $)^{14}$. This is because the worker is a free man. The market protects it against the arbitrary actions of an employer, which like workers - depends solely on the power of consumers. Here you can see that human work not only flows from a person, but is focused on it and towards it ${ }^{15}$. In the system of the division of labor, it also has a significant social dimension, because working "means to do something for someone" 16 . Working for Mises is only a means, not an end in itself. This ability of purposefully using one's strength to eliminate discomfort indicates the causal dependence of work on the human "I"; that is, the priority of the subject of work on the very act of labor ${ }^{17}$.

\section{Common good}

In this direction of the common good, understood as redistribution, unfortunately, tend some contemporary schools of the most recent Catholic Social Teaching ${ }^{18}$. Mises emphasizes that in the free market, consumers themselves choose and determine both the quantity and quality of manufactured goods. According to Mises basic human rights are the right to determine the purpose of their own actions and to choose means to achieve them. Of course, the question arises whether that, which is my good, can also be good for others. By caring for his own well-understood interest, individual works for the development of social cooperation and peaceful coexistence, and does not have to renounce his prosperity for the good of society. With this reasoning Mises fits into the personalist perspective of the concept of the common good initiated by Pius XII $(+1958)$, which is an evolution in the sense of the common good that has taken place in the Church.

The Pope states in the well-known definition of the common good that these are "external conditions necessary for all citizens to develop their 
abilities, their material, intellectual, and religious life"19. It is not political power, but citizens as persons naturally endowed with reason and freedom, created in the image of God - that is, conscious subjects of their rights and duties - are first responsible for their own material and spiritual development $^{20}$. The task of the state is therefore to create the right social conditions for this integral development of the person to be possible. Public authorities must respect the pluralism of values and opinions, and thus can no longer be responsible for promoting and striving for shared material goods, as well as for spiritual values, including religious ones. Mises's reasoning helps to deepen the contemporary concept of the common good. Of course, for understandable reasons, Mises as an economist omits in his writings the whole sphere of transcendence as unavailable to scientific cognition. But the individual in action in Mises still possesses the quality of the transcendent being in its entirety. All laws in laissez-faire, that is, political, economic, and religious freedoms, flow from the basic right to determine the purpose for which a person aspires, and to choose freely means to lead him or her. The entire socio-political system should be directed, according to Mises, to defend this fundamental right.

The means to achieve this is the minimum state, whose only task is to protect citizens and their property against external aggression. The state has no right to interfere in the world created by individuals the world of goals and means that lead to them. These views, until the encyclical Centesimus annus which appeared in 1991, had been in sharp contradiction with everything that was said on this subject in the Church Social Teaching before John Paul II. The Magisterium of the Catholic Church strongly emphasized the role of the state as a designer of the common good, responsible for its achievement. The encyclical Centesimus annus rejects the omnipotence of the state in the design of the common good and grants a very limited right of the state to intervene in the sphere of economics, which does not mean, however, that John Paul II reduced the role of the state to purely negative functions.

\section{Conclusion}

The free market is very often accused of concentrating too much on the production of goods, which becomes an end in itself. Analyzing Mises's thought, I see that production of goods is only a byproduct of human freedom. Man needs material things to achieve his goals. Following the line of the Austrian economist's reasoning, I can say that a free market economy 
surpasses other economic systems not only in terms of production and distribution of material goods, but above all because it gives an acting person the satisfaction of achieving goals that the free person puts in front of him or her and I do not mean only those earthly ones, but also the transcendent aims.

Here we can see a similarity to the thought of John Paul II, whose personalism had a huge impact on the contemporary social doctrine of the Church. The convergence of the title of his book The Acting Person ${ }^{21}$, which he wrote as a professor of ethics before he later became the pope, with the economic treaty of Mises's Human Action is not accidental. There is an evident influence of the Austrian School of Economics on the most freemarket oriented social encyclical Centesimus annus. This happened probably thanks to Rocco Buttiglione, an Italian Catholic philosopher and friend of John Paul II, who during the preparation of this encyclical gave to the pope the works of Mises and Friedrich von Hayek (+1992). Michael Novak (+2017), a catholic American thinker, recalls that Hayek, a few months before his death, had a long conversation with the Holy Father in Vatican City.

The Pope did not support a free market economy simply because it is perceived as the most effective means and way of exchanging goods and services. This is certainly a very strong argument for the free market, but the Pope has another, stronger one. His attention is focused on man and his or her dignity, which is realized in free action. Mises points to this as well in Human Action when he aptly emphasizes that the desire to be rich is no more or less rational than the desire to become as poor as a Buddhist monk ${ }^{22}$.

\section{N O T E S}

1 The book was based on a doctoral dissertation in the field of moral theology entitled Man and his Action in the Socio-Economic Space According to Ludwig von Mises, a Representative of the Austrian School of Economics. A Theological and Moral Study at the Cardinal Stefan Wyszynski University of Warsaw in Poland.

2 John Paul II (1991). Encyclical Letter Centesimus annus. Vatican City: Libreria Editrice Vaticana, p. 35.

3 M. Gronbacher, p. 6-7.

4 J. Smith (1995). Natural Law and Personalism in Veritatis Splendor. Veritatis splendor. American Responses (M.E. Allsopp, J.J. O'Keefe). Kansas City, p. 194-207.

5 Vatican Council II (1965). Pastoral Constitution on the Church in the Modern World "Gaudium et spes". Vatican City: Libreria Editrice Vaticana, p. 71.

${ }^{6}$ It is important to notice that many modern Austrian economists reject the doctrine of consumer sovereignty because it implies a condition of violent submission. I agree with 
Murray N. Rothbard for whom the most obvious drawback of this theory is its name itself: "The term 'consumers' sovereignty" is a typical example of the abuse, in economics, of a term ("sovereignty") appropriate only to the political realm and is thus an illustration of the danger of the application of metaphors taken from other disciplines. "Sovereignty" is a quality of ultimate political power; it is a power resting on the use of violence. In a purely free society, each individual is sovereign over his own person and property, and it is therefore this self-sovereignty which obtains on the free market. No one is "sovereign" over anyone else's actions or exchanges. Since the consumers do not have the power to coerce producers into various occupations and work, the former are not "sovereign" over the latter." [Rothbard M. N. (2004). Man, Economy, and State with Power and Market. Auburn, p. 630].

7 John Paul II (1981). Encyclical Letter Laborem exercens. Vatican City: Libreria Editrice Vaticana, p. 14.

8 John Paul II, Centesimus, p. 32.

9 Ibid., p. 43.

10 Soto J. H. de (2000). The Mystery of Capital, Why capitalism triumphs in the west and fails everywhere else. New York, p. 48-49.

11 John Paul II, Laborem, p. 2.

12 John Paul II, Centesimus, p. 32.

13 Ibid., no. 43.

14 T. Styczen (1986). The Personal Dignity of the Subject of Labor as a Source of its Sense and Value. John Paul II, Laborem exercens, Text and commentary (J. Chmiel, S. Ryłko) [polish edition]. Lublin, p. 109.

15 Pontifical Council for Justice and Peace (2004). Compendium of the Social Doctrine of the Church. Vatican City: Libreria Editrice Vaticana (English edition, Washington, D.C.: U.S. Conference of Catholic Bishops, 2005), p. 494.

16 John Paul II, Centesimus, p. 31.

17 T. Styczen, p.98.

18 Curran C.E. (1987). The Common Good and Official Catholic Social Teaching. The Common Good and U.S. Capitalism (O.F. Williams, J. Houck). Lanham, p. 122-124.

19 Pius XII, The Internal Order of States and People. Christmas Message of 1942. http://www.papalencyclicals.net/Pius12/ P12CH42.HTM 2.HTM [2 Jan. 2014].

20 Vatican Council II (1965). Declaration on Religious Freedom "Dignitatis humanae". Vatican City: Libreria Editrice Vaticana, 6. Pastoral Constitution 26, p. 74.

${ }^{21}$ K. Wojtyla (1979). The Acting Person. Trans. by A. Potocki, Dordrecht: R. Reidel Publishing Company.

22 L. von Mises (1966). Human Action. A Treaties on Economics. Chicago, p. 884.

\section{R E F E R E N C E S}

Curran C.E. (1987). The Common Good and Official Catholic Social Teaching. The Common Good and U.S. Capitalism (O.F. Williams, J. Houck). Lanham

Gronbacher M.A. (1998). Economic personalism. A New Paradigm for a Humane Economy. Grand Rapids: Acton Institute 
J. Smith (1995). Natural Law and Personalism in Veritatis Splendor. Veritatis splendor. American Responses (M.E. Allsopp, J.J. O’Keefe). Kansas City, 194-207

John Paul II (1981). Encyclical Letter Laborem exercens. Vatican City: Libreria Editrice Vaticana

John Paul II (1991). Encyclical Letter Centesimus annus. Vatican City: Libreria Editrice Vaticana, 35

Mises L. von. (1966). Human Action. A Treaties on Economics. Chicago, 884.

Pius XII (1942). The Internal Order of States and People. Christmas Message of 1942. http://www.papalencyclicals.net/Pius12/ P12CH42.HTM 2.HTM [2 Jan. 2014].

Pontifical Council for Justice and Peace (2004). Compendium of the Social Doctrine of the Church. Vatican City: Libreria Editrice Vaticana (English edition, Washington, D.C.: U.S. Conference of Catholic Bishops, 2005).

Rothbard M. N. (2004). Man, Economy, and State with Power and Market. Auburn, 630

Soto J. H. de (2000). The Mystery of Capital, Why capitalism triumphs in the west and fails everywhere else. New York, 48-49.

Styczen T. (1986). The Personal Dignity of the Subject of Labor as a Source of its Sense and Value. John Paul II, Laborem exercens, Text and commentary (J. Chmiel, S. Ryłko) [polish edition]. Lublin, 109

Vatican Council II (1965). Declaration on Religious Freedom "Dignitatis humanae". Vatican City: Libreria Editrice Vaticana, 6. Pastoral Constitution 26, 74

Vatican Council II (1965). Pastoral Constitution on the Church in the Modern World "Gaudium et spes". Vatican City: Libreria Editrice Vaticana, 71

Wojtyla K. (1979). The Acting Person. Trans. by A. Potocki, Dordrecht: R. Reidel Publishing Company 